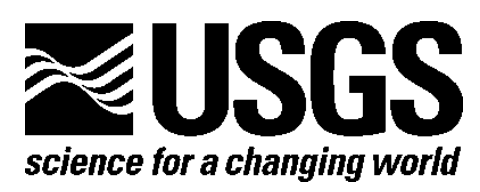

\title{
An Index to PGE-Ni-Cr Deposits and Occurrences in Selected Mineral-Occurrence Databases
}

By J. Douglas Causey, John P. Galloway, and Michael L. Zientek

Open-File Report 2009-1045

U.S. Department of the Interior

U.S. Geological Survey 


\section{U.S. Department of the Interior \\ KEN SALAZAR, Secretary}

\section{U.S. Geological Survey \\ Suzette M. Kimball, Acting Director}

\section{U.S. Geological Survey, Reston, Virginia 2009}

For product and ordering information:

World Wide Web: http://www.usgs.gov/pubprod

Telephone: 1-888-ASK-USGS

For more information on the USGS - the Federal source for science about the Earth, its natural and living resources, natural hazards, and the environment:

World Wide Web: http://www.usgs.gov

Telephone: 1-888-ASK-USGS

\section{Suggested citation:}

Causey, J.D., Galloway, J.P., and Zientek, M.L., 2009, An index to PGE-Ni-Cr deposits and occurrences in selected mineral-occurrence databases: U.S. Geological Open-File Report 2009-1045

[http://pubs.usgs.gov/of/2009/1045/]

Any use of trade, product, or firm names is for descriptive purposes only and does not imply endorsement by the U.S. Government.

Although this report is in the public domain, permission must be secured from the individual copyright owners to reproduce any copyrighted material contained within this report. 


\section{Contents}

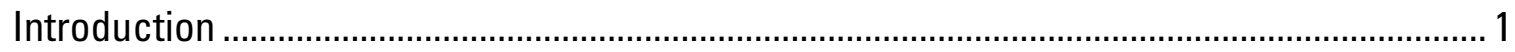

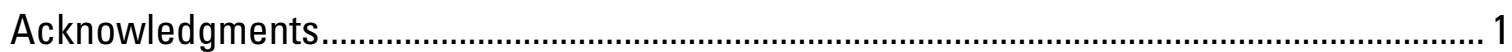

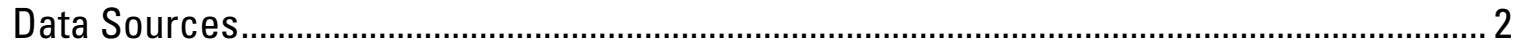

Data Format and Presentation .................................................................................................... 3

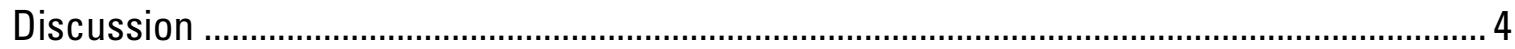

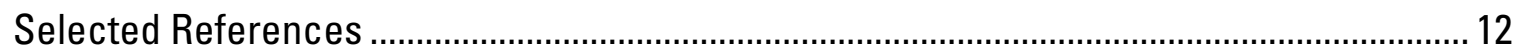

\section{Figures}

Figure 1. Location of sites (black dots) in Ni_Cr_PGE_Index.mdb. ....................................... 4

Figure 2. Locations of 5,194 site records (blue dots) that list only chromium as

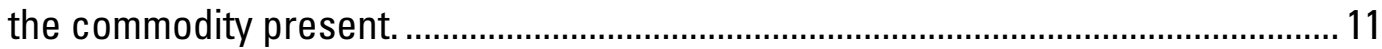

Figure 3. Locations of 1,623 site records (red dots) that list only nickel as the commodity present.

Figure 4. Locations of 905 site records (red dots) that list only contain only platinum, palladium, and/or PGE as the commodities present.

\section{Tables}

Table 1. Database fields and definitions for Ni_Cr_PGE table.............................................. 2

Table 2. Database fields and definitions for References table............................................... 2

Table 3. Distribution of records by country. ........................................................................ 5

Table 4. Example of two records for a site in which the commodity order was switched in the data source.

Table 5. Example of two records for a site that do not have an identical list of commodities. 5b. Example of five records for a site that demonstrate differences in name and commodity.

Table 6. Example of five records for a site that demonstrate differences in name and commodity. 


\title{
An Index to PGE-Ni-Cr Deposits and Occurrences in
}

\section{Selected Mineral-0ccurrence Databases}

\author{
By J. Douglas Causey, John P. Galloway, and Michael L. Zientek
}

\section{Introduction}

Databases of mineral deposits and occurrences are essential to conducting assessments of undiscovered mineral resources (Singer, 1993). In the USGS's (U.S. Geological Survey) global assessment of undiscovered resources of copper, potash, and the platinum-group elements (PGE), only a few mineral deposit types will be evaluated. For example, only porphyry-copper and sediment-hosted copper deposits will be considered for the copper assessment. To support the global assessment, the USGS prepared comprehensive compilations of the occurrences of these two deposit types in order to develop grade and tonnage models and delineate permissive areas for undiscovered deposits of those types (Singer and others, 2002; Singer and others, 2005; Singer and others, 2008; and Cox and others, 2003).

This publication identifies previously published databases and database records that describe PGE, nickel, and chromium deposits and occurrences. Nickel and chromium were included in this overview because of the close association of PGE with nickel and chromium mineralization. Users of this database will need to refer to the original databases for detailed information about the deposits and occurrences. This information will be used to develop a current and comprehensive global database of PGE deposits and occurrences.

\section{Acknowledgments}

Several people provided assistance in preparing this report. Ken Assmus scanned and used optical-character recognition software to create digital versions of reports only available in hard copy. David Sinclair and Lesley Chorlton graciously provided us copies of the PGE-Ni-Cr database developed for the Geological Survey of Canada World Minerals Geoscience Database Project (1998-2003). Mark Mihalasky helped us understand how to create KML files. Warren J. Nokleberg and Robert J. Miller provided digital files they derived from the Aerogeologica metallogenic map of the former Soviet Union. Technical reviews of this report were provided by Lorre Moyer and Dan Mosier. 


\section{Data Sources}

We compiled mineral databases for large regions of the globe and extracted site data containing PGE elements, nickel, or chromium from 55 published databases and 1 unpublished USGS database from 46 publications cited in the bibliography and referenced in our database.

The data were stored in a variety of formats, including Oracle, ESRI ArcInfo coverage and shapefile, dBASE, Access, FileMaker, and Excel. Data were imported into an Access 2000 database and selected information compiled in a new table.

This compilation includes fields for: the name of the deposit or occurrence; information about its location; the commodities present; the type of record; a reference to the database; and the record number in the published database. In some cases, no pertinent information was available for one or more of these fields. Fifteen records did not have latitude and longitude, and 946 did not have a name.

The information is stored in two tables in the database-one table contains the name, location, commodities, record number, and record type (Ni_Cr_PGE); the other table contains the references (References). Table 1 summarizes the fields and their definitions in the Ni_Cr_PGE table, and table 2 summarizes the fields in the associated References table.

Table 1. Database fields and definitions for Ni_Cr_PGE table.

\begin{tabular}{llll}
\hline \multicolumn{1}{c}{ Field name } & Data type & Field size & \multicolumn{1}{c}{ Field definition } \\
\hline Site_ID & Number & Long Integer & Unique number for each record \\
Name & Text & 150 & Name of the site as reported in the source database \\
WGS84_Lat & Number & Double & Latitude (in decimal degrees), WGS 84 datum \\
WGS84_Lon & Number & Double & Longitude (in decimal degrees), WGS 84 datum \\
Commod_gp & Text & 125 & List of commodities, in order presented in source database \\
Src_Rec_No & Text & 50 & Unique record number used in source database \\
Record_tp & Text & 100 & Description of what the record represents \\
Country & Text & 50 & Country where site is located \\
State & Text & 50 & State or province where site is located \\
Ref_no & Number & Long Integer & Number of reference in Reference table \\
\hline
\end{tabular}

Table 2. Database fields and definitions for References table.

\begin{tabular}{llll}
\multicolumn{1}{c}{ Field name } & Data type & Field size & \multicolumn{1}{c}{ Field definition } \\
\hline Ref_no & Number & Long Integer & Unique number for each record \\
Reference & Memo & NA & Reference in U.S. Geological Survey bibliographic style \\
Ref_st_frm & Text & 255 & Reference short form-Author, date abbreviated reference \\
\hline
\end{tabular}

We normalized commodity information in the databases in order to extract the records of sites that contain PGE, nickel, or chromium. This involved converting the names of each elemental commodity to a standardized form of their chemical symbol (for example, CHROMIUM, chromium, or $\mathrm{CR}$ were converted to $\mathrm{Cr}$ ), and the list of commodities was then concatenated into a comma-separated string. The original commodity order was not changed. If there was some indication that a commodity 
or commodities were of secondary importance, they were set off with a semicolon. Otherwise, the meaning of the commodity order is unknown.

We did not attempt to eliminate duplicate records for a deposit or occurrence nor attempt to reconcile discrepancies in names or locations. However, we did correct the latitude and longitude values that were reversed in three of the databases (latitude values in longitude field and longitude values in latitude field). Most of the databases identified the country. However, for about 1,700 records that did not specify a country, a name was obtained using ArcGIS and a global country-boundary GIS database.

Values in the field describing the type of record (Record_tp) were from the original datasets, and may be in languages other than English. We corrected some minor typographical errors.

From 56 databases, we extracted 17,969 records for this database. Users are encouraged to refer to the original published databases for detailed information about each record.

\section{Data Format and Presentation}

The result of the compilation is presented in five formats: a Microsoft Access 2000 database, an ESRI format shapefile, an Arc Reader file, a delimited ASCII text file, and a Google Earth format KML file.

The Access database can be used by Access version 2000 and above, as well as by other software that reads Access 2000 database format. The database only contains two tables-a table of basic information about each site record and a table of references.

The shapefile (ESRI format) is made from the Ni_Cr_PGE table. For those databases that did not specify the datum of the latitude and longitude, the WGS 84 datum is assumed. For those whose datum is specified and it is not WGS 84, the locations are converted to WGS 84 using the ArcGIS v. 9.2 projection tool. The GDA 94 datum uses the WGS 84 ellipsoid, and the NAD 83 datum has essentially the same latitude/longitude, so those values were not modified either. Data in the Feature Attribute table can be joined to the References table in the Access database using the Ref_no field. This table was not converted to DBF format because the field with the complete reference is a memo field and data would be truncated.

The Arc Reader file (Ni_Cr_PGE_Index Report.pmf) provides a view of the data in a GIS-like view and the individual points can be queried. The view is the same as shown in figure 1 . The file can be read by Arc Reader, a free program that runs on several operating systems. The program and system requirements can be found at http://www.esri.com/software/arcgis/arcreader/download.html.

There are two ASCII text files, one containing the information from the Access Ni_Cr_PGE table and one created from the Reference table. These files were exported from the Access database using the pipe $(\mid)$ symbol as a field delimiter. The first line contains the field names.

A KML file was generated from ArcMap v. 9.3 using the Export to KML toolbar. All fields in the Access Ni_Cr_PGE table are included in the KML. This file can be used by Google Earth to show locations of the sites on the Earth's surface. No accuracy is implied. The sites may have been mislocated in the original database, and no corrections were done. 


\section{Discussion}

The 17,969 records in 126 countries or territories are shown in fig. 1 . The distribution, by country, is listed in table 3. The bulk of the sites are in the United States, followed by Canada, Australia, and Russia. This distribution is more a function of the database developers, who were located in the respective countries, than a real indication of the true distribution of deposits. Also, duplication of records is common, with some sites possibly being listed at least 5 times because many of the databases overlap in their area of coverage and some sites are repeated even within a single database. There was no attempt to remove duplicates, because this database is designed primarily as a pointer to other databases.

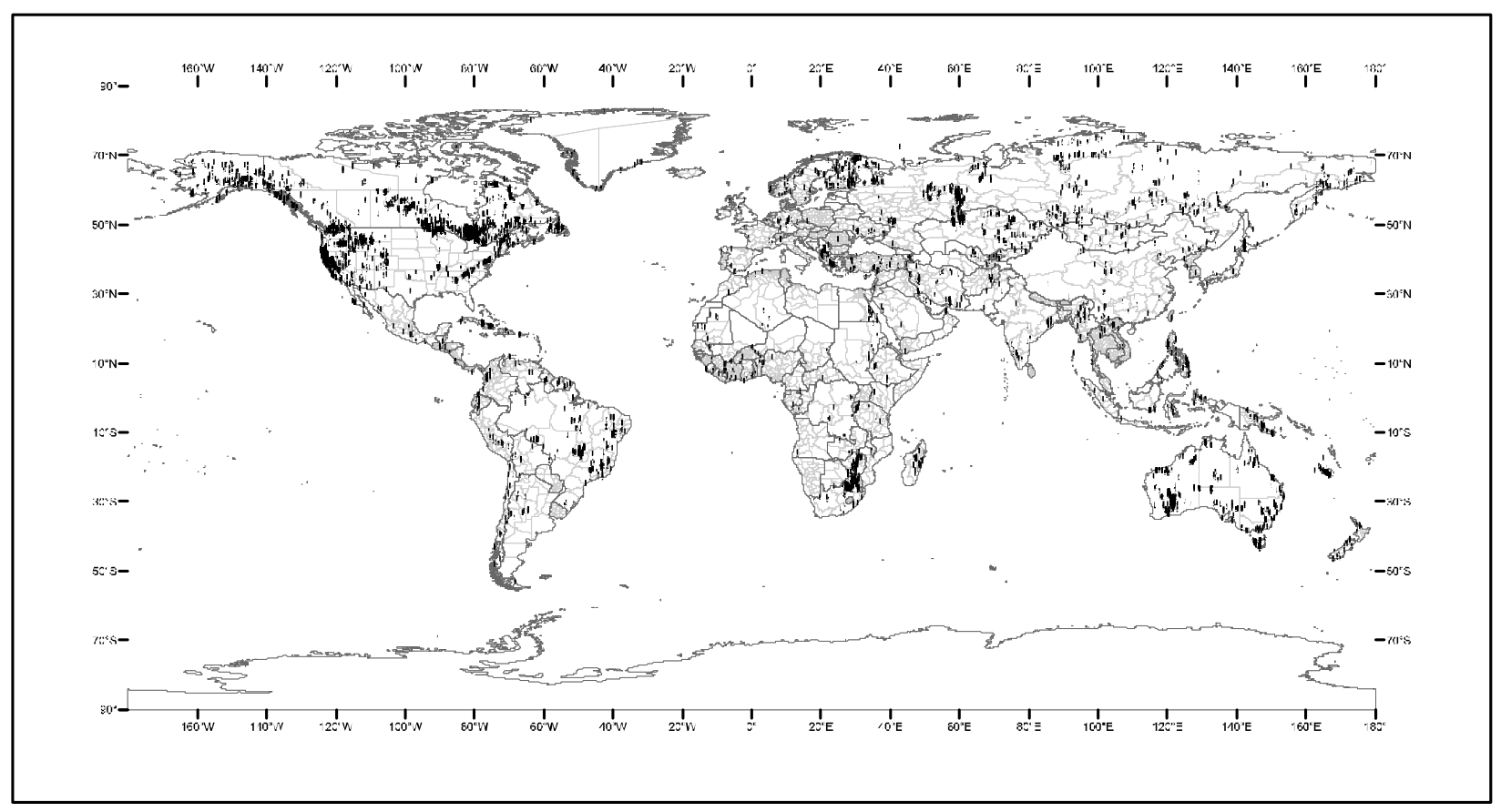

Figure 1. Location of sites (black dots) in Ni_Cr_PGE_Index.mdb. 
Table 3. Distribution of records by country.

\begin{tabular}{|c|c|}
\hline Country & $\begin{array}{l}\text { Number } \\
\text { of } \\
\text { Records }\end{array}$ \\
\hline Afghanistan & 20 \\
\hline Albania & 42 \\
\hline Algeria & 16 \\
\hline Angola & 3 \\
\hline Argentina & 53 \\
\hline Armenia & 8 \\
\hline Australia & 2,091 \\
\hline Azerbaijan & 1 \\
\hline Belgium & 1 \\
\hline Benin & 13 \\
\hline Bolivia & 29 \\
\hline Bosnia and Herzegovina & 2 \\
\hline Botswana & 24 \\
\hline Brazil & 549 \\
\hline Bulgaria & 2 \\
\hline Burkina Faso & 12 \\
\hline Burundi & 19 \\
\hline Cambodia & 2 \\
\hline Cameroon & 2 \\
\hline Canada & 3,634 \\
\hline Central African Republic & 1 \\
\hline Chad & 3 \\
\hline Chile & 47 \\
\hline China & 105 \\
\hline Colombia & 43 \\
\hline
\end{tabular}




\begin{tabular}{|c|c|}
\hline Country & $\begin{array}{c}\begin{array}{c}\text { Number } \\
\text { of } \\
\text { Records }\end{array} \\
\end{array}$ \\
\hline Costa Rica & 11 \\
\hline Côte d'Ivoire & 33 \\
\hline Cuba & 205 \\
\hline Cyprus & 4 \\
\hline Czech Republic & 3 \\
\hline Democratic Republic of the Congo & 16 \\
\hline Denmark & 67 \\
\hline Dominican Republic & 12 \\
\hline Ecuador & 29 \\
\hline Egypt & 31 \\
\hline Eritrea & 2 \\
\hline Ethiopia & 19 \\
\hline Finland & 196 \\
\hline France & 7 \\
\hline French Guiana & 11 \\
\hline Gabon & 1 \\
\hline Georgia & 2 \\
\hline Germany & 26 \\
\hline Ghana & 8 \\
\hline Greece & 29 \\
\hline Guatemala & 28 \\
\hline Guinea & 4 \\
\hline Guyana & 7 \\
\hline Haiti & 1 \\
\hline Honduras & 2 \\
\hline Hungary & 1 \\
\hline
\end{tabular}




\begin{tabular}{|c|c|}
\hline Country & $\begin{array}{c}\text { Number } \\
\text { of } \\
\text { Records }\end{array}$ \\
\hline India & 138 \\
\hline Indonesia & 53 \\
\hline Iran & 54 \\
\hline Iraq & 5 \\
\hline Italy & 9 \\
\hline Jamaica & 1 \\
\hline Japan & 76 \\
\hline Kazakhstan & 396 \\
\hline Kenya & 9 \\
\hline Kyrgyzstan & 12 \\
\hline Laos & 12 \\
\hline Liberia & 4 \\
\hline Macedonia & 7 \\
\hline Madagascar & 83 \\
\hline Malawi & 2 \\
\hline Malaysia & 7 \\
\hline Mali & 1 \\
\hline Mauritania & 25 \\
\hline Mexico & 69 \\
\hline Mongolia & 52 \\
\hline Morocco & 18 \\
\hline Mozambique & 3 \\
\hline Myanmar & 49 \\
\hline Namibia & 1 \\
\hline New Zealand & 47 \\
\hline Niger & 6 \\
\hline
\end{tabular}




\begin{tabular}{|c|c|}
\hline Country & $\begin{array}{c}\text { Number } \\
\text { of } \\
\text { Records }\end{array}$ \\
\hline Nigeria & 1 \\
\hline North Korea & 2 \\
\hline Norway & 52 \\
\hline Oman & 8 \\
\hline Pakistan & 6 \\
\hline Panama & 4 \\
\hline Papua New Guinea & 74 \\
\hline Peru & 31 \\
\hline Philippines & 133 \\
\hline Poland & 2 \\
\hline Portugal & 1 \\
\hline Puerto Rico & 2 \\
\hline Republic of the Congo & 3 \\
\hline Romania & 2 \\
\hline Russia & 1,604 \\
\hline Saudi Arabia & 9 \\
\hline Senegal & 1 \\
\hline Serbia & 32 \\
\hline Sierra Leone & 17 \\
\hline Slovenia & 1 \\
\hline Solomon Islands & 2 \\
\hline Somalia & 3 \\
\hline South Africa & 493 \\
\hline South Korea & 5 \\
\hline Spain & 25 \\
\hline Sudan & 19 \\
\hline
\end{tabular}




\begin{tabular}{|c|c|}
\hline Country & $\begin{array}{l}\text { Number } \\
\text { of } \\
\text { Records }\end{array}$ \\
\hline Suriname & 11 \\
\hline Swaziland & 4 \\
\hline Sweden & 39 \\
\hline Syria & 1 \\
\hline Taiwan & 3 \\
\hline Tajikistan & 2 \\
\hline Tanzania & 18 \\
\hline Territory of New Caledonia and Dependencies & 101 \\
\hline Thailand & 10 \\
\hline Togo & 5 \\
\hline Turkey & 75 \\
\hline Uganda & 5 \\
\hline Ukraine & 80 \\
\hline United Arab Emirates & 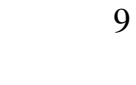 \\
\hline United Kingdom & 7 \\
\hline United States & 6,248 \\
\hline Uzbekistan & 27 \\
\hline Venezuela & 15 \\
\hline Vietnam & 13 \\
\hline West Bank & 2 \\
\hline Yemen & 3 \\
\hline Zambia & 7 \\
\hline Zimbabwe & 136 \\
\hline Total Records & 17,969 \\
\hline
\end{tabular}

Some observations or interpretations may be possible from the limited information in this database. However, the user should consider some important points in any interpretation based only on the data in this database. The order in which commodities are listed in a database is not a reliable 
indicator of their relative amount or importance (table 4). Also, the list of commodities may not be a true or complete listing of what is present at a site (tables 5, 6).

Table 4. Example of two records for a site in which the commodity order was switched in the data source.

\begin{tabular}{|l||l|l|l|l|}
\hline Site_ID & Name & WGS84_Lat & \multicolumn{1}{|c|}{ WGS84_Lon } & \multicolumn{1}{c|}{ Commod_gp } \\
\hline \hline 206217 & APEX & 49.4108417 & -93.6158 & $\mathrm{Ni}, \mathrm{Cu}$ \\
\hline 208262 & APEX & 49.410556 & -93.6325 & $\mathrm{Cu}, \mathrm{Ni}$ \\
\hline
\end{tabular}

Table 5. Example of two records for a site that do not have an identical list of commodities. 5b. Example of five records for a site that demonstrate differences in name and commodity.

\begin{tabular}{|l|l|l|l||l|}
\hline \multicolumn{1}{|c|}{ Site_ID } & Name & WGS84_Lat & WGS84_Lon & \multicolumn{1}{c|}{ Commod_gp } \\
\hline \hline 207311 & Alotta & 47.4500008 & -79.2333298 & $\mathrm{Ni}, \mathrm{Cu}, \mathrm{PGE}, \mathrm{Co}$ \\
\hline \hline 12081482 & Alotta & 47.4680233 & -79.2542965 & $\mathrm{Cu}, \mathrm{Ni} ; \mathrm{Co}, \mathrm{Ag}$ \\
\hline
\end{tabular}

Table 6. Example of five records for a site that demonstrate differences in name and commodity.

\begin{tabular}{|l|l|l|l||l|}
\hline \multicolumn{1}{|c|}{ Site_ID } & \multicolumn{1}{|c|}{ Name } & WGS84_Lat & WGS84_Lon & \multicolumn{1}{c|}{ Commod_gp } \\
\hline \hline 207771 & Amandelbult & -24.7833 & 27.2833 & PGE \\
\hline \hline 180350 & Amandelbult & -24.76667 & 27.33333 & PGE; $\mathrm{Pt}, \mathrm{Ni}, \mathrm{Cu}$ \\
\hline \hline 8574 & Amandelbult & -24.774 & 27.335 & Pt, Ni, Cu, Cr \\
\hline \hline 12160189 & Amandelbult Mine & -24.7817 & 27.28333 & PGE, Ni, Cu \\
\hline 86539 & Amandelbult-Northam & -24.8 & 27.25 & PGE, Cr \\
\hline
\end{tabular}

While we recognize that there are caveats on applying any interpretation to specific records, it is still possible to extract some generalizations from this compilation. For example, because of limited information in many of the source databases, no information was extracted about the source rock. Given the caveats listed, we made some inferences based on the commodity suites. About 29 percent of the records $(5,194)$ list chromium as the only commodity (fig. 2). We infer that most of these represent chromite or chromitite bodies hosted in magmatic, mafic/ultramafic intrusions. Another 1,623 records list nickel as the only commodity (fig. 3), and 905 have PGE, platinum, palladium, or some combination of these as the only commodity(ies) (fig. 4). These may also represent magmatic, mafic/ultramafic intrusions. 


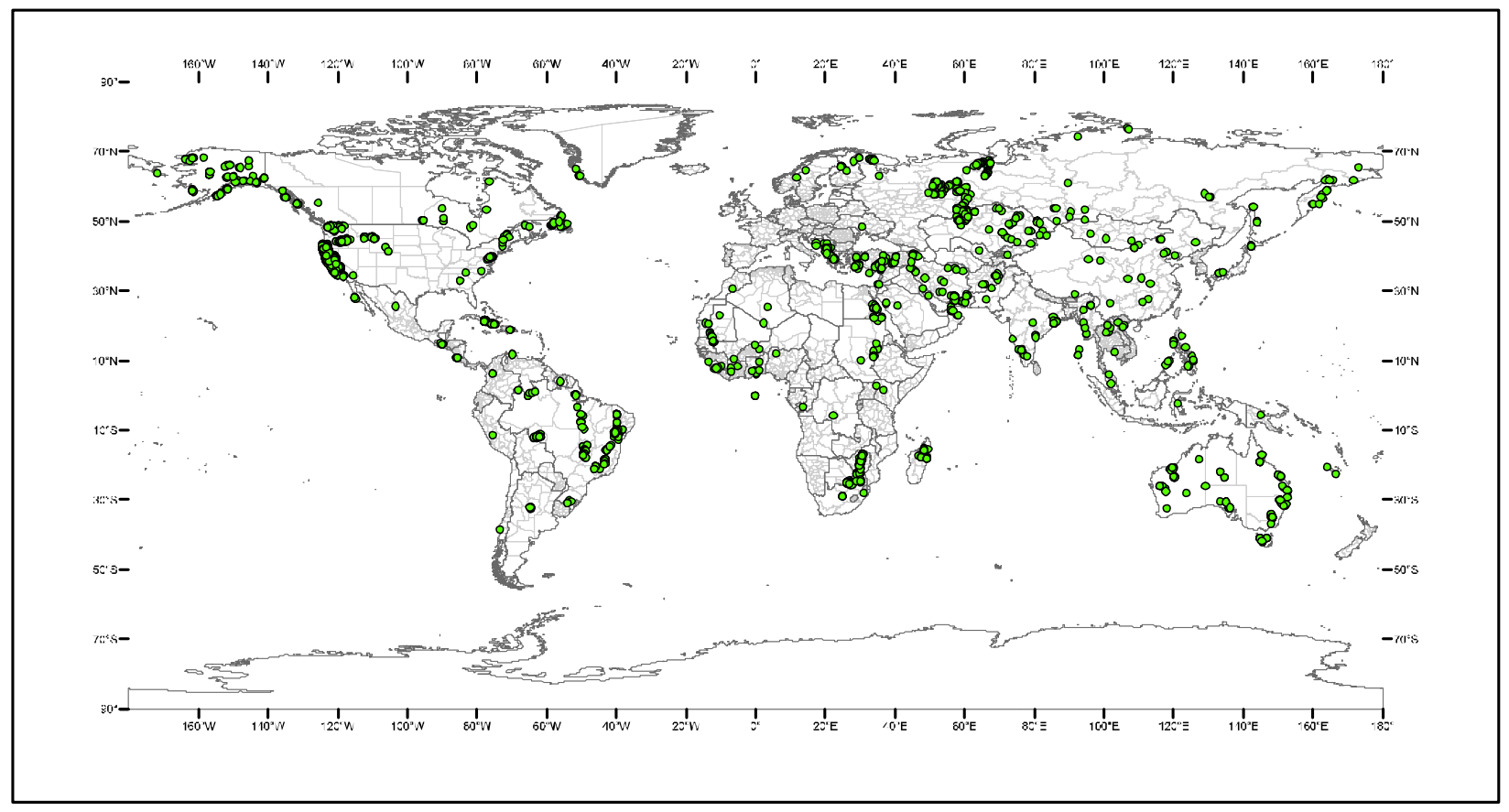

Figure 2. Locations of 5,194 site records (blue dots) that list only chromium as the commodity present.

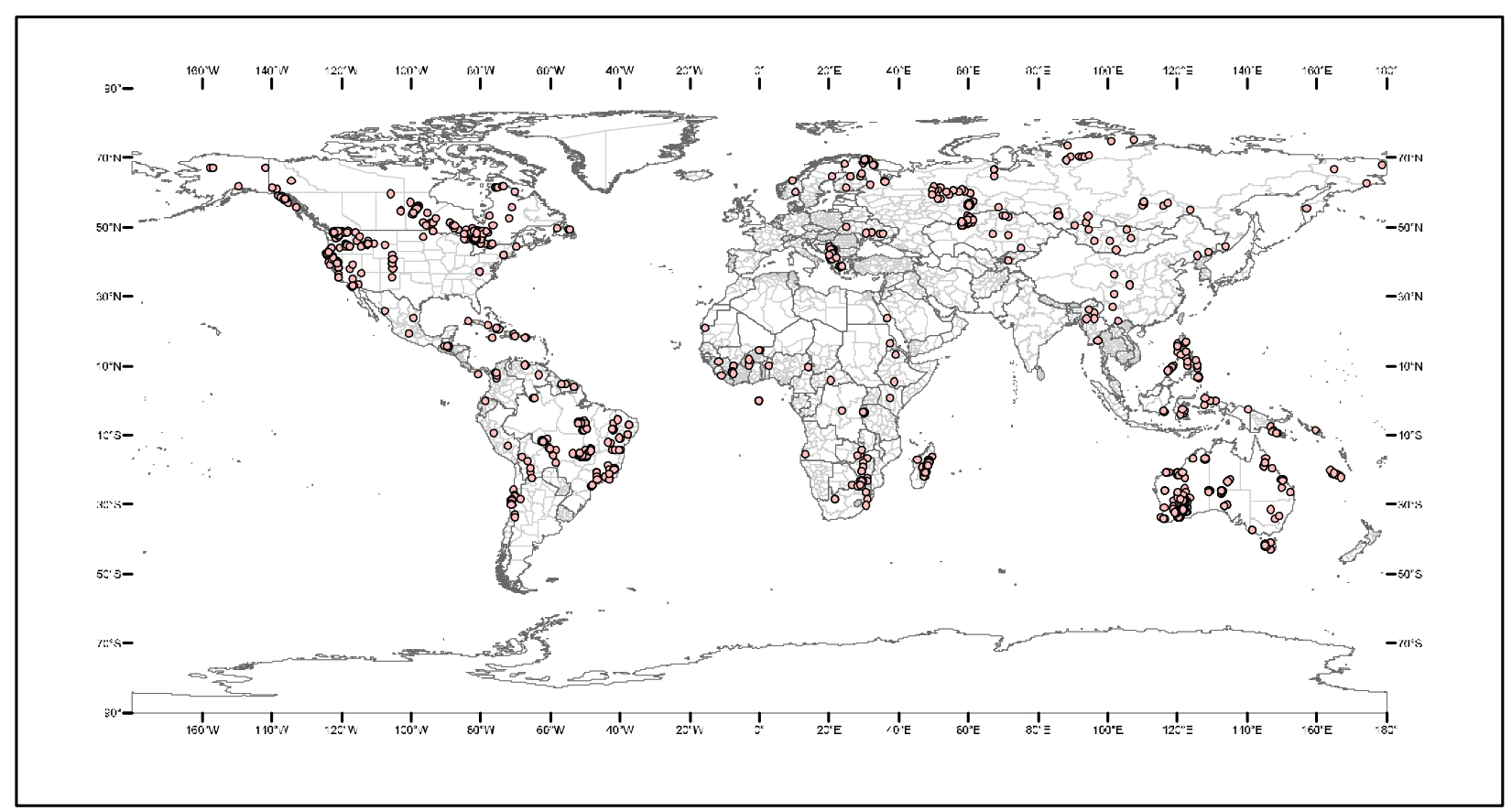

Figure 3. Locations of 1,623 site records (red dots) that list only nickel as the commodity present. 


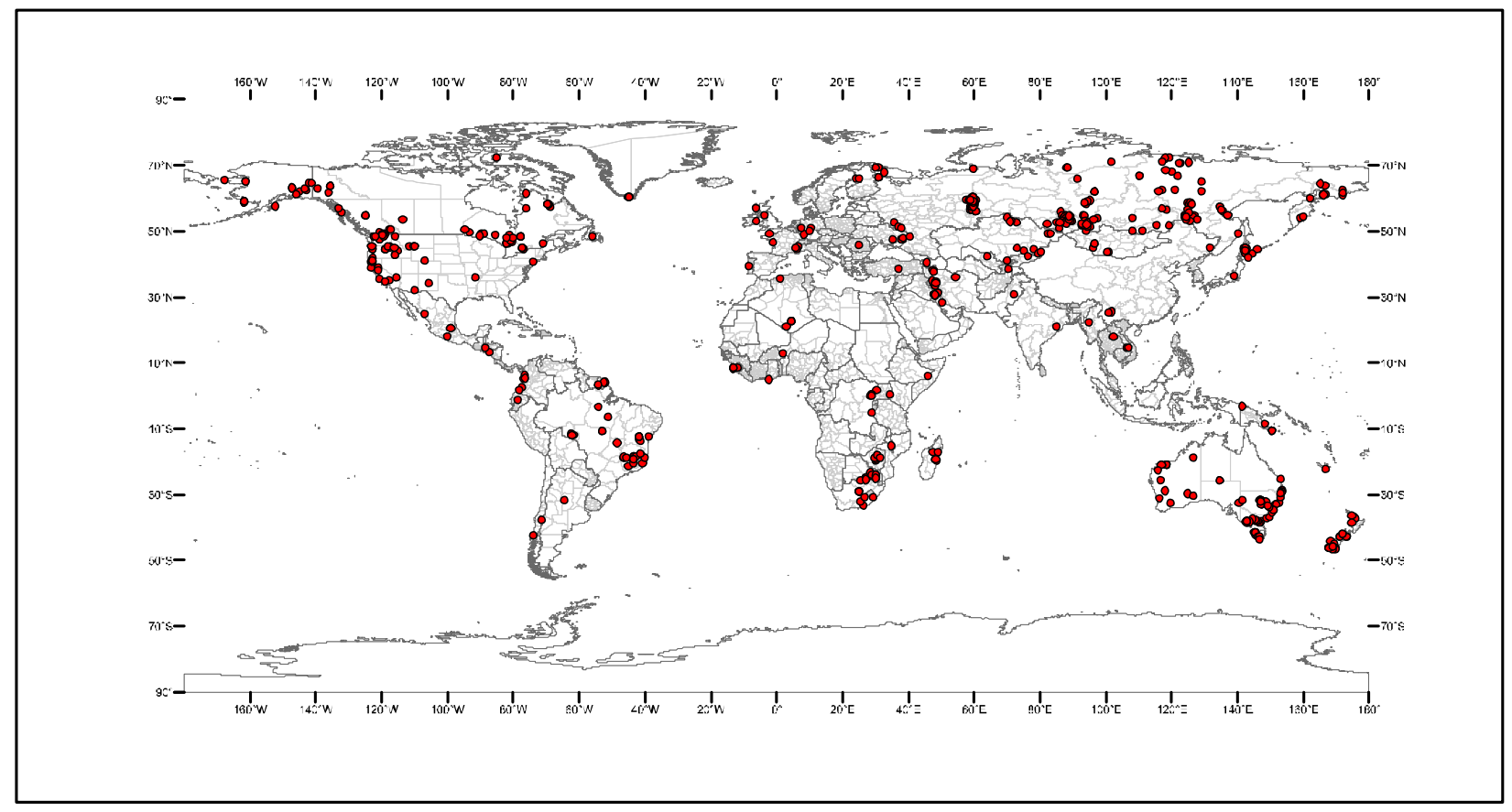

Figure 4. Locations of 905 site records (red dots) that list only contain only platinum, palladium, and/or PGE as the commodities present.

Examination of a few databases that do contain source-rock information indicates that these assumptions are generally true, but not always. For example some of the chromium-only records are for placer deposits. Records of sites that have nickel as the only commodity also include weathered products of mafic/ultramafic rocks-laterites.

Other possible interpretations from commodities or commodity assemblages are that gold + platinum indicates a placer deposit (513 records). Deposits containing silica, gemstone, phosphate, borate, limestone, feldspar, petroleum, barite, base metals, tungsten, or uranium probably do not have a magmatic, mafic/ultramafic host rock. A small percentage of the records are in this category.

In general, a record that contains $\mathrm{Ni} \pm \mathrm{Cr} \pm \mathrm{PGE} \pm \mathrm{Co}( \pm \mathrm{Cu})$ most commonly indicates a magmatic, mafic- or ultramafic-intrusion source. A record that only lists gold + platinum may indicate a placer deposit, and a record that contains one or more nonmetallic commodities probably does not describe a magmatically hosted deposit.

\section{Selected References}

Banerjee, J., Ghosh, S., and Mukherjee, A., compilers, 2001, Mineral atlas of India: Hyderabad, India, Geological Society of India, 64 p., 24 sheets, scale 1:2,000,000.

Besaire, Henri, 1964, Madagascar, carte géologique: Madagascar, Service géologique, 1 map on 3 sheets, scale 1:1,000,000. 
BRGM, 2007, Le Système d'Information Géographique sur les ressources minérales de la Guyane:

Paris, France, SIG Guyane Française Géologie and Métallogénie [http://gisguyane.brgm.fr./, last accessed Jul. 07, 2007].

Center for Mineral Resources, 1999, University of Arizona-Industry-USGS Mexico Consortium: University of Arizona Mexico Consortium March 1999 Release Notes, 45 p, CD-ROM.

Center for Russian and Central Asian Mineral Studies, 2006a, Belarus mineral database: London, Natural History Museum, Center for Russian and Central Asian Mineral Studies, CD-ROM.

Center for Russian and Central Asian Mineral Studies, 2006b, Ukraine GIS database: London, Natural History Museum, Center for Russian and Central Asian Mineral Studies, CD-ROM.

Cox, D.P., Lindsay, D.A., Singer, D.A., Moring, B.C., and Diggles, M.F., 2003, Sediment-hosted copper deposits of the world-deposit models and database: U.S. Geological Survey Open-File Report 03-107, ver. 1.3 [http://pubs.usgs.gov/of/2003/of03-107/, last accessed Nov. 23, 2007].

Davenport, P.H., Nolan, L.W., Butler, A.J., Wagenbauer, H.A., and Honarvar, P., 1999, The geoscience atlas of Newfoundland, version 1.1: Newfoundland Department of Mines and Energy, Geological Survey Open File NFLD/2687, scale 1:1,000,000, CD-ROM.

Eckstrand, O.R., Good, D.J., Yakubchuk, A., and Gall, Q., compilers, 2007, World distribution of Ni, $\mathrm{Cu}, \mathrm{PGE}$, and $\mathrm{Cr}$ deposits and camps: Geological Survey of Canada [This is an update of Eckstrand, O.R., and Good, D.J., 2000, World distribution of nickel deposits: Geological Survey of Canada Open File 3791a] [http://gdr.nrcan.gc.ca/minres/metadata_e.php?id=11, last accessed Mar. 19, 2008].

Ewers, G.R., Evans, N., and Kilgour, B., compilers, 2001, MINLOC mineral localities database: Geoscience Australia, scale 1,100,000 [http://www.ga.gov.au/general/technotes/20011023_32.jsp, last accessed Oct. 15, 2004].

Ewers, G.R., Evans, N., Hazell, M., and Kilgour, B., compilers, 2002, OZMIN mineral deposits database [Digital Datasets]: Geoscience Australia AGSO Record 2000/18, 103 p., scale 1:100,000 [http://www.ga.gov.au/general/technotes/20011023_32.jsp, last accessed Apr. 15, 2008].

Fitch, D.C., 2000a, Mexico activities map and database of active metals exploration and mining properties (2000 edition): Reno, Nev., http://www.igeologist.com, scale 1:500,000, CD-ROM.

Fitch, D.C., 2000b, Mexico mineral occurrences map and GIS database: Reno, Nev., http://www.igeologist.com. scale 1:2,500,000, CD-ROM.

Geological Survey of Denmark and Greenland (GEUS), 2006a, Greenland mineral occurrence mapEntire Greenland-Geological environments and related mineral occurrences: Geological Survey of Denmark (GEUS) [http://www.geus.dk/gmom/gmom-uk.htm, last accessed Nov. 2, 2006].

Geological Survey of Denmark and Greenland (GEUS) 2006b, Greenland mineral occurrence mapRegional data compilations-West Greenland $\left(66^{\circ}-70^{\circ} 15^{\prime}\right)$ the Palaeoproterozoic Nagssugtoqidian, Rinkian Orogen and the adjacent North Atlantic Craton: Geological Survey of Denmark (GEUS) [http://www.geus.dk/gmom/gmom-uk.htm, last accessed Nov. 2, 2006].

Geological Survey of Denmark and Greenland (GEUS), 2006c, Greenland mineral occurrence mapRegional data compellations-South Greenland south of $62^{\circ} \mathrm{N}$, the Palaeoproterozoic Ketilidian Orogen and the southernmost part of the North Atlantic Craton: Geological Survey of Denmark (GEUS), [http://www.geus.dk/gmom/gmom-uk.htm, last accessed Nov. 2, 2006].

Geological Survey of Finland, 2009, Fennoscandian ore deposit database [online]: Geological Survey of Finland [http://en.gtk.fi/ExplorationFinland/fodd/, last accessed Feb. 10, 2009].

Geological Survey of South Australia, compiler, 1999, South Australia Geoscientific GIS dataset, December 1999 release: Department of Primary Industries and Resources South Australia, Mineral Exploration Data Packages, 1, scale 1:2,000,000, CD-ROM. 
Geological Survey of South Australia, compiler, 2004, South Australia State MGA GIS dataset:

Department of Primary Industries and Resources South Australia, DVD-ROM.

Geological Survey of Western Australia, 2004, Record 13/2000-Mines and mineral deposits of Western Australia: digital extract from MINEDEX — an explanatory note: Department of Industry Resources Western Australia GeoView WA Data Center Unique Record ANZWA 1220000385 [http://mapserver.doir.wa.gov.au/datacentre/, last accessed Jul. 6, 2004].

Head Research Information Computer Center (GlavNIVC) of the Russian Ministry of Natural Resources, 1998, Natural resources GIS of Russia: American Geological Institute, scale $1: 2,500,000$, CD-ROM.

Hulbert, Larry, and Scoates, Jon, 2001, Digital map and database of magmatic Ni-Cu \pm PGE occurrences and mafic-ultramafic bodies in Manitoba: Manitoba Industry, Trade and Mines Economic Geology Report ER2000-1, scale 1:1,500,000, CD-ROM.

Hulbert, Larry, and Slimmon, Bill, 2000, Map and database of magmatic Ni-Cu \pm PGE occurrences and mafic-ultramafic intrusions in Saskatchewan: Saskatchewan Energy and Mines Miscellaneous Report 2000-5, scale 1:850,000, CD-ROM.

Hulbert, Larry, Vaillancourt, Christine, and Sproule, Rebecca, 2002, Magmatic Ni-Cu \pm PGE occurrences and mafic-ultramafic bodies in Ontario, provincial GIS and database: Ontario Geological Survey Miscellaneous Release-Data 100, scale 1:2,000,000, CD-ROM.

Kamitani, Masaharu, Okumura, Kimio, Teraoka, Yoji, Miyano, Sumiko, and Watanabe, Yasusi, 2007, Mineral resources map of East Asia: Geological Survey of Japan, scale 1:3,000,000 [http://www.gsj.jp/Map/EN/overseas.htm, last accessed Feb. 9, 2009].

Kirkham, R.V., and Raefer, A.B., 2003, Selected world mineral deposits database: Geological Survey of Canada Open File 1801, 83 p., CD-ROM.

Makepeace, A.J., Stasiuk, M.V., Krauth, O.R., Hickson, C.J., Cocking, R.B., and Ellerbeck, D.M., compliers, 2002, Multinational Andean Project-GeoData: Publicación Geológica Multinational [Multinational Geological Publication] no. 3, 2 CD-ROMs. [alternate series-Geological Survey of Canada, Contribution Series 2004003].

Martini, J.E.J., Vorster, C.J., Oosterhuis, W.R., and Wolmarans, L.G., 2001, Digital metallogenic map of South Africa and the Kingdoms of Lesotho and Swaziland: Council for Geoscience (Geological Survey), South Africa, scale 1:1,000,000, CD-ROM.

Monthel, J., Vadala, P., Leistel, J.M., Cottard, F., Ilic, M., Strumberger A., Tosovic, R., and Stepanovic, A., 2002, Mineral deposits and mining districts of Serbia_compilation map and GIS databases: BRGM/RC-51448-FR, 69 p., 1 plate, CD-ROM.

Naumova, V.V., Miller, R.J., Patuk, M.I., Kapitanchuk, M.Y., Nokleberg, W.J., Khanchuk, A.I., Parfenov, L.M., and Rodiono, S.M., 2006, Geographic Information Systems (GIS) spatial data compilation of geodynamic, tectonic, metallogenic, mineral deposit, and geophysical maps and associated descriptive data for northeast Asia: U.S. Geological Survey Open-File Report 20061150, CD-ROM, [http://pubs.usgs.gov/of/2006/1150/, last accessed March 19, 2009].

Nokleberg, W.J., West, T.D., Dawson, K.M., Shpikerman, V.I., Bundtzen, T.K., Parfenov, L.M., Monger, J.W.H., Ratkin, V.V., Baranov, B.V., Byalobzhesky, S.G., Diggles, M.F., Eremin, R.A., Fujita, Kazuya, Gordey, S.P., Gorodinskiy, M.E., Goryachev, N.A., Feeney, T.D., Frolov, Y.F., Grantz, Arthur, Khanchuck, A.I., Koch, R.D., Natalin, B.A., Natapov, L.M., Norton, I.O., Patton, W.W., Jr., Plafker, George, Pozdeev, A.I., Rozenblum, I.S., Scholl, D.W., Sokolov, S.D., Sosunov, G.M., Stone, D.B., Tabor, R.W., Tsukanov, N.V., and Vallier, T.L., 1998, Summary terrane, mineral deposit, and metallogenic belt maps of the Russian Far East, Alaska, and the Canadian Cordillera: U.S. Geological Survey Open-File Report 98-136, CD-ROM, [http://pubs.usgs.gov/of/1998/of98-136/, last accessed March 19, 2009]. 
Northern Territory Geological Survey, 2003, Northern Territory Mineral Occurrence Database (MODAT): Northern Territory Geological Survey Dataset exports [http://www.minerals.nt.gov.au/pls/portal30/docs/FOLDER/DBIRD_NTGS/INFO_CENTRE/A TTACHMENTS/DATASET_EXPORTS/MODAT070403.ZIP, last accessed Nov. 3, 2004].

Ontario Geological Survey, 2002, Mineral deposit inventory (ver. 2 MDI2): Ontario Geological Survey, CD-ROM; Oct. 2002 release.

Peters, S.G., Ludington, S.D., Orris, G.J., Sutphin, D.M., Bliss, J.D., and Rytuba, J.J., eds., and the U.S. Geological Survey-Afghanistan Ministry of Mines Joint Mineral Resource Assessment Team, 2007, Preliminary non-fuel mineral resource assessment of Afghanistan 2007: U.S. Geological Survey Open-File Report 2007-1214 [http://pubs.usgs.gov/of/2007/1214/, last accessed Dec. 2, 2008].

Petrov, O., Shatov, V., Kondian, K., Markov, G., Guriev, G., Seltmann, R., and Armstrong, R., eds., 2007, Mineral deposits of the Urals 1M scale map and database-ArcView 3.2 GIS package: London, Natural History Museum, Center for Russian and Central Asian Mineral Studies, 91 p., scale 1:1,000,000.

Quebec Geomining Information System [SIGÉOM], 2008, Metallic deposit (mineralized body): Gouvernement du Québec Ressources Naturelles et Faune Online Product Services_-Mines—Esigeom à la carte [http://www.mrnf.gouv.qc.ca/english/products-services/mines.jsp, last accessed Apr. 1, 2008].

Rodnov, Yu.N., Belkina, I.L., Bystrova, G.P., Zabotikin, L.V., Larin, A.M., Sviridov, A.P., Simonova, L.S., and Smolenkov, V.I., authors, and Rundkuist, D.V., and Belkina, I.L., eds., 2001 [2002], Mineragenic map of Russian Federation and adjacent states (with boundaries of former USSR): Saint Petersberg, VSEGEI Publishing House, Ministry of Natural Resources of the Russian Federation, State Research and Development Enterprise "Aerogeolgica," 49 p., Excel workbook, and 1 map on 16 sheets, scale 1:2,500,000.

Salas, G.P., 1975, Carta y provincias metalogenéticas de la República Mexicana: Consejo de Recursos Minerales Publicación 21E, 2d edition, 242 p., 1 sheet.

Schjøth, F., Garde, A.A., Jørgensen, M.S., Lind, M., Moberg, E., Nielsen, T.F.D., Rasmussen, T.M., Secher, K., Steenfelt, A., Stendal, H., Thorning, L., and Tukiainen, T., 2000, Mineral resource potential of South Greenland-the CD-ROM: Danmarks og Grønlands Geologiske Undersøgelse [GEUS] Rapport 2000/57, 38 p., scale 1:500,000, CD-ROM.

Schobbenhaus, Carlos, Gonçalves, J.H., Santos, J.O.S., Abram, M.B., Neto, R.L., Muniz de Matos, G.M., Vidotti, R.M., Ramos, M.A.B., and Alves de Jesus, J.D., 2004, Carta geológica do Brasil ao milionésimo, system de informações geográficas-SIG (edição 2004) [Geological map of Brazil, 1:1,000,000 scale, geographical information system-GIS (2004 edition)]: Brasília, CPRM, Programa Geologico do Brasil, scale 1:1,000,000, CD ROM [set of 40 CD ROM disks, in Portuguese].

Seltmann, Reimar, Shatov, Vitaly, and Yakubchuk, Alexander, eds., 2005, Mineral deposits database and thematic maps of central Asia, scale 1.5 million-ArcView 3.2 and MapInfo 6.0 (7.0) GIS Packages: London, Natural History Museum, Center for Russian and Central Asian Mineral Studies, 117 p., scale 1:1,500,000, CD-ROM.

Singer, D.A., 1993, Basic concepts in three-part quantitative assessments of undiscovered mineral resources: Natural Resources Research, v. 2, no. 2, p. 69-81.

Singer, D.A., Berger, V.I., and Moring, B.C., 2002, Porphyry copper deposits of the world-database, maps, and preliminary analysis: U.S. Geological Survey Open-File Report 02-268 [http://geopubs.wr.usgs.gov/open-file/of02-268/; last accessed Dec. 17, 2002]. 
Singer, D.A., Berger, V.I., and Moring, B.C., 2005, Porphyry copper deposits of the world-database, map, and grade and tonnage models: U.S. Geological Survey Open-File Report 2005-1060, v. 1 [http://pubs.usgs.gov/of/2005/1060/; last accessed June 17, 2005].

Singer, D.A., Berger, V.I., and Moring, B.C., 2008, Porphyry copper deposits of the world-database and grade and tonnage models: U.S. Geological Survey Open-File Report 2008-1155 [http://pubs.usgs.gov/of/2008/1155/, last accessed July 11, 2008].

U.S. Geological Survey, 2008, Mineral Resources Data System (MRDS): [http://minerals.usgs.gov/factsheets/MRDS_Broch.html, last accessed Sep. 20, 2008].

Veselinovic-Williams, M., and Frost-Killian, S., 2003 [2007], Digital international metallogenic map of Africa: Council for Geoscience, South Africa, and Commission for the Geologic Map of the World (CGMW), scale 1:5,000,000, CD-ROM.

Yukon Geological Survey, 2005, Yukon Minfile 2005: Yukon Energy, Mines and Resources [http://geology.yk.net/minfile/products.html, last accessed Mar. 31, 2006].

Zappettini, E.O., ed., 1998, Mapa metalogenético de la República Argentina (versión preliminar) [Metallogenic map of Argentina (preliminary version)]: Servicio Geologico Minero Argentino (SEGEMAR) Anales 32/D, scale 1:2,500,000, CD-ROM.

Zappettini, E.O., 2005, Metallogenic map of South America, second edition: Buenos Aires, Servicio Geológico Minero Argentino, Instituto de Geología y Recursos Minerales Anales no. 44, p. 260269, and a database, scale 1:5,000,000.

Zaw, Khin, Burrett, C.F., Berry, R.F., and Bruce, E., 1999, Geological, tectonic and metallogenic relationships of mineral deposits in mainland Southeast Asia (P390A): University of Tasmania Centre for Ore Deposits Research AMIRA Project P390A, CD-ROM. 